\title{
PREDICTING THE BIOLOGICAL EFFECTS OF MOBILE PHONE RADIATION: ABSORBED ENERGY LINKED TO THE MRI-OBTAINED STRUCTURE
}

\author{
Dejan KRSTIĆ ${ }^{1}$, Darko ZIGAR ${ }^{1}$, Dejan PETKOVIĆ ${ }^{1}$, Dušan SOKOLOVIĆ ${ }^{2}$, Boris ĐINĐIĆ ${ }^{2}$, \\ Nenad CVETKOVIĆ ${ }^{3}$, Jovica JOVANOVIĆ ${ }^{2}$ and Nataša ĐINĐIĆ ${ }^{2}$
}

University of Niš, Faculty of Occupational Safety in Niš, University of Niš, Faculty of Medicine ${ }^{2}$, University of Niš, Faculty of Electronic Engineering ${ }^{3}$, Niš, Serbia

Received in September 2012

CrossChecked in September 2012

Accepted in February 2013

\begin{abstract}
The nature of an electromagnetic field is not the same outside and inside a biological subject. Numerical bioelectromagnetic simulation methods for penetrating electromagnetic fields facilitate the calculation of field components in biological entities. Calculating energy absorbed from known sources, such as mobile phones when placed near the head, is a prerequisite for studying the biological influence of an electromagnetic field. Such research requires approximate anatomical models which are used to calculate the field components and absorbed energy. In order to explore the biological effects in organs and tissues, it is necessary to establish a relationship between an analogous anatomical model and the real structure. We propose a new approach in exploring biological effects through combining two different techniques: 1) numerical electromagnetic simulation, which is used to calculate the field components in a similar anatomical model and 2) Magnetic Resonance Imaging (MRI), which is used to accurately locate sites with increased absorption. By overlapping images obtained by both methods, we can precisely locate the spots with maximum absorption effects. This way, we can detect the site where the most pronounced biological effects are to be expected. This novel approach successfully overcomes the standard limitations of working with analogous anatomical models.
\end{abstract}

KEY WORDS: accurate locating, computational bioelectromagnetic modelling, electromagnetic field, specific absorption rate (SAR)

Technical, mathematical and technological discoveries have significantly contributed to the science of medicine in the $20^{\text {th }}$ century. They influenced the development of medical diagnostics and new methods of treatment. The need for regular feedback and interpretation of information obtained from technical procedures and their application in medicine has always existed. The development of technology and telecommunications brought about electromagnetic waves that had not existed in the natural environment before, which is why electromagnetic waves are undesirable phenomena for most biological entities and are often called electromagnetic pollution or electromagnetic smog.

The majority of electrical devices generate electromagnetic radiation which leaves undesirable effects on a biological entity (1). More often than not, these effects can be divided into thermal and nonthermal (2).

In order to conduct a profound study on the influence of electromagnetic radiation on biological entities, one needs to be familiar with the characteristics of the source; the form and the type of wave propagation in free space; the way of propagation; 
absorption and reflection from the objects affected by the wave; and the characteristics of absorption into biological entities. Only a part of the energy that reaches a biological entity is absorbed, and it is that portion which causes a biological effect. Since the energy absorbed in this entity is not homogeneously distributed, one needs to know the distribution of this energy throughout the entire volume of the biological entity. This is the initial condition for understanding the biological effects of electromagnetic radiation on living organisms. Therefore, it is necessary to use these results and link them with biochemical, biological and medical research in order to draw proper conclusions. However, one should always bear in mind that the biological effects of electromagnetic waves are frequency-dependent.

\section{MATERIALS AND METHODS}

\section{Basic concept for investigating biological effects}

The biological effects of electromagnetic radiation are studied through investigations and research such as numerical bioelectromagnetic modelling, experimental (in vivo and in vitro) investigations and epidemiological studies. The process which helps us get accurate results can be defined by the algorithm shown in Figure 1. A multidisciplinary approach is crucial to obtain relevant information on the biological effects. The technical sources of radiation and their key features are best known to the engineers engaged in their design, while the process of propagation and absorption is analysed by applying the physical laws of propagation, technical methods of analysis and simulation (3-5), and knowledge on the electromagnetic properties of biological materials (6).

In order to determine the biological effects of electromagnetic waves - electromagnetic radiation - it is extremely significant to define the amount of absorbed energy of the incidental wave and its distribution in the volume of the object. The specifications for these processes are shown in Figure 2.

\section{Proposed method for the computer-assisted investigation of the biological effects of EM radiation}

During the last decade, the need for theoretical research has led to the development of models and tools for the numerical simulation of an entire research

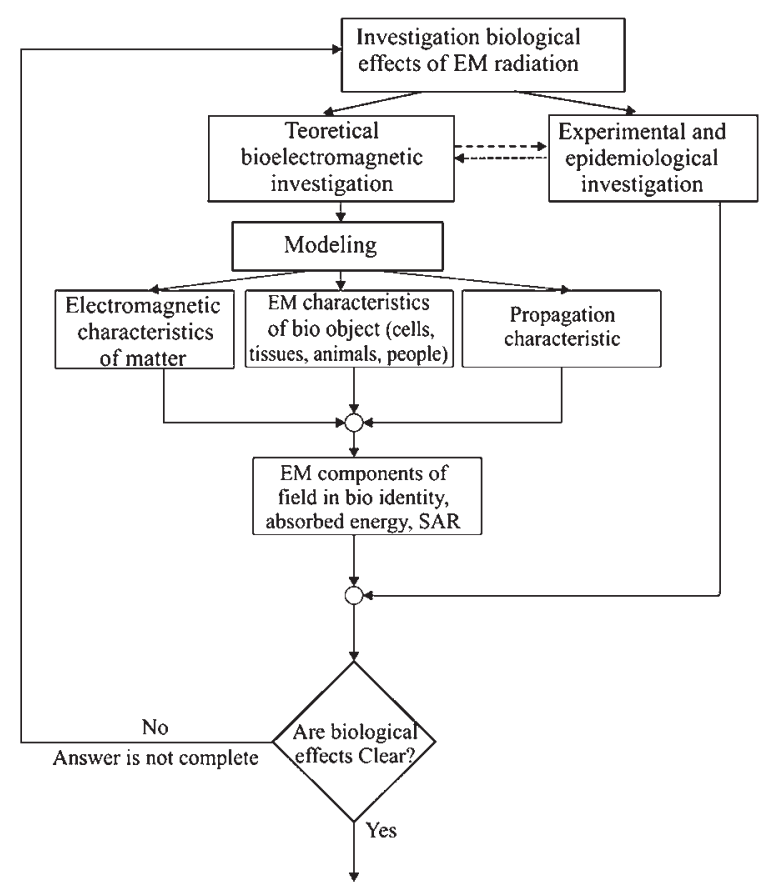

Figure 1 The function algorithm for the research of biological effects of EM radiation according to (5).

process (Figure 2) $(4,5,7)$. New methods and software packages have evolved into powerful tools for calculating the distribution of absorbed energy in a biological subject.

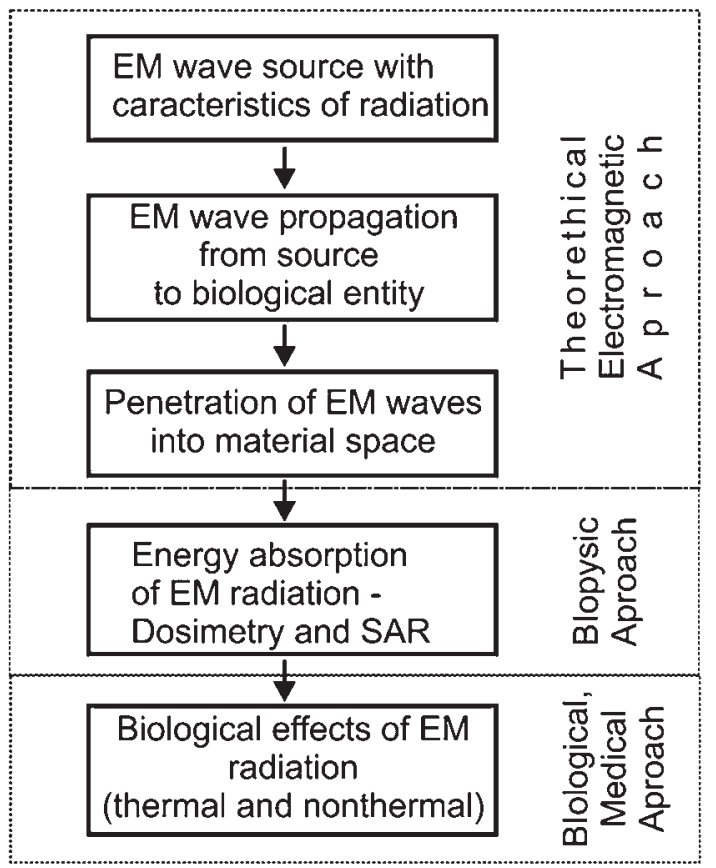

Figure 2 The procedure of examining biological effects of EM radiation emitted from the source of known characteristics according to (5). 
The models used in these calculations should be as similar as possible to anatomical models, and there is always a certain degree of approximation within the model and averaging of the real structure of the tissue. In most cases, we use models of body parts or the entire body obtained by Computer-Aided Design (CAD).

It is rather difficult to recreate the real internal structure of tissues and organs. That is why we apply simplified organ and tissue modelling. This makes it possible to model tissues from homogeneous layers that constitute the skin, subcutaneous tissue, bones, skulls, etc., whereas organs are modelled as ellipsoidal structures resembling for instance the brain, eyes, kidneys, or stomach. Such models are suitable for use in numerical simulation programmes alongside source models (mobile phones, antennas, etc.). The obtained results of the field components, absorbed energy and SAR values in such models, although numerically correct, are not very useful for medical professionals since these results cannot be easily associated with biological effects (8). This is due to the fact that they do not entirely reflect the true structure, thus making it difficult to localise anatomical structures. For example, in a descriptive model of the head, it is not possible to locate the pineal gland and calculate the amount of energy absorbed in it, although some studies have indicated that the pineal gland is particularly sensitive to the effects of electromagnetic radiation (12).

It is our intention to relate the results of the electromagnetic fields calculation in models of biological subjects with the real structure of biological tissues and organs of a biological subject. Therefore, this paper proposes a combination of two procedures: 1) numerical electromagnetic simulation used to calculate the field components in a similar anatomical model; and 2) Magnetic Resonance Imaging (MRI) used to obtain the precise location of the places. This combination will be accomplished by overlapping the images of the object (such as images of the human head) obtained by both procedures (Figure 3).

Thus we can determine the precise location of the place with maximum absorption effects, which points to the location of the expected pronounced biological effects. Medical diagnostic methods, such as computed tomography (CT), X-ray computed tomography, and the like, provide good accuracy and distinctiveness in defining the locations of organs and tissues.

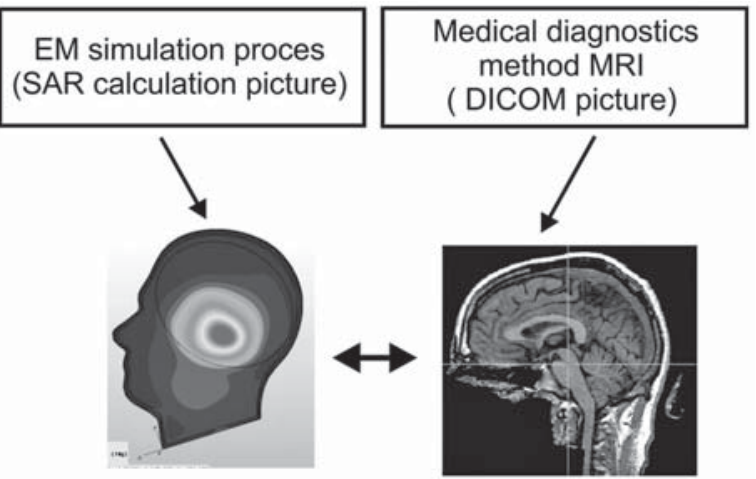

Figure 3 The investigation procedure of biological effects of EM radiation based on overlapped images

A modern diagnostic tool of choice is magnetic resonance imaging (MRI), as it provides a good contrast between different soft tissues, the brain, muscles, heart and cancers.

In order to properly combine the two procedures, it is necessary to have a digital graphic view (picture) of a biological object or a part of that object (e.g. head). It is rather frequent to obtain a Digital Imaging and Communications in Medicine (DICOM) study after the body has been subjected to diagnostic techniques. The DICOM study is a collection of digital body images in different sections of the coordinate axes. DICOM is a standard for handling, storing, printing, and transmitting information in medical imaging.

We assumed that it is possible to link the results of modelling absorbed energy in tissues with the real structure of the tissue, and thus locate the parts of tissue where the biological effects of radiation can be seen.

\section{Applying the suggested procedure on the human and head and mobile phone and the electromagnetic modelling of biological tissues}

The proposed procedure has been applied to investigate the effects of mobile phone radiation in the area of the human head. This procedure can also be applied for other sources and biological entities, regardless of whether they involve the entire body or just one part.

To study the propagation of electromagnetic waves, one needs to know three physical constants: $\varepsilon$ - dielectric constant, $\sigma$ - electric conductivity and $\mu$ - magnetic permeability. The values of these constants are experimentally determined for all human tissues at all frequencies within the range in which technical devices emit electromagnetic radiation (6). These values slightly differ among studies, depending on 
whether they are based on experimental data obtained from living (in vivo) or dead tissue; or from the Debye approximation or Cole-Cole approximations (7-9).

\section{The human head and mobile phone models}

The human head has been modelled according to the EN 50361 SAM Phantom head (Specific Anthropomorphic Mannequin) from the 3D CAD Design Software made by SolidWorks (USA), originally as a NURBS 3D model (Non-Uniform Rational B-Splines). This NURBS model was converted into a corresponding 3D Solid STL model (13). The basic model has been modified by adding layers, the brain and the ear cavity. The model of the human head consists of three layers and two domains. The skin, fat, and muscles comprise the layers with a constant thickness of $2 \mathrm{~mm}$. The domains include bone tissue and the brain, both of which are modelled in accordance with the remainder of the total volume (14). The human head is anatomically modelled with average anthropometric dimensions $(\mathrm{h}=256 \mathrm{~mm}$, $\mathrm{w}=166 \mathrm{~mm}$, and $\mathrm{d}=260 \mathrm{~mm}$ ).

The human brain model is inscribed in a parallelepiped whose dimensions are $174 \mathrm{~mm} x$ $145 \mathrm{~mm} \times 170 \mathrm{~mm}$. Each outer layer or domain contains inner layers or domains. We assumed that the ear canal was $25 \mathrm{~mm}$ long and the constant diameter of cross section $7 \mathrm{~mm}$. The cross-section of the human head model is presented in Figure 4.

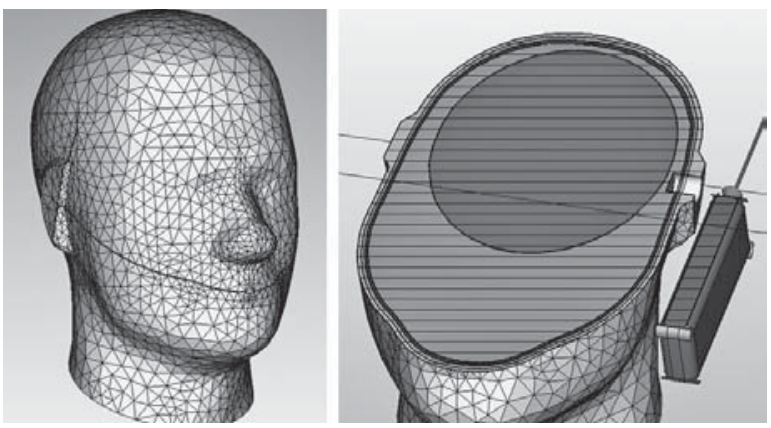

Figure 4 Human head numerical model and cross-section according to (16).

For this purpose, the characteristics of the biological tissues $\left(\varepsilon_{\mathrm{r}}\right.$ and $\left.\sigma\right)$ at $900 \mathrm{MHz}$, which is the most frequently used frequency in GSM mobile communication, are presented in Table 1 (6-9). Mass density $(\rho)$ is frequency-independent but is different for each tissue observed.
Table 1 Characteristics of tissues at $900 \mathrm{MHz}$ according to (16)

\begin{tabular}{lccc}
\hline Tissue & $\varepsilon_{\mathbf{r}}$ & $\sigma / \mathbf{S} \mathbf{~ m}^{-1}$ & $\rho / \mathbf{k g ~ m}^{-3}$ \\
\hline skin & 41.4053 & 0.8667 & 1100 \\
\hline fat & 5.4619 & 0.0510 & 1100 \\
\hline muscle & 56.8790 & 0.9953 & 1040 \\
\hline bone & 12.4537 & 0.1433 & 1850 \\
\hline brain & 45,8000 & 0,7660 & 1030 \\
\hline
\end{tabular}

$\varepsilon_{r}-$ relative dielectric constant, $\sigma$ - electric conductivity and $\rho$ - mass density

In this investigation, a monoblock phone with a Planar Inverted-F Antenna (PIFA) (Figure 5) was used. In our calculations, the reference power of the phone was $1 \mathrm{~W}$, defined according to the Standard IEEE C.95.3.

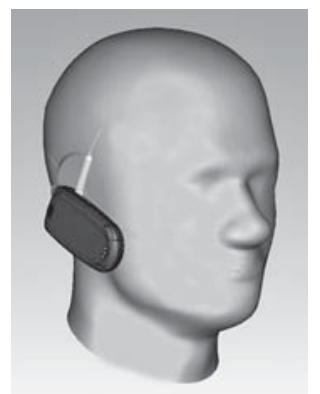

Figure 5 Human head model with mobile phone with Planar Inverted-F Antenna (PIFA)

\section{Calculating the electromagnetic field in head tissue}

The calculation of the components of an electromagnetic (EM) field in non-homogenous media is very complex and requires various numerical techniques. There are many numerical methods: Finite Difference Method (FDM), Finite Difference Time Domain Method (FDTD), Finite Element Method (FEM), Charge Simulation Method (CSM), Surface Charge Simulation Method (SCSM), Boundary Integral Equation Method, Method of Moments (MoM), Finite Integration Technique (FIT), Multiple Multiple Method(MMP), Generalized Multiple Technique (GMT), etc. (5).

For calculating the electromagnetic field presented in this paper, the Finite Integration Technique (FIT) was used. The Finite Integration Technique $(2,10)$ is a consistent geometric discretization method which turns Maxwell's equations into a set of algebraic matrix equations (Figure 6).

The spatial discretization of Maxwell's equations is finally executed on these two orthogonal grid systems. The electric grid voltages (e), magnetic facet fluxes (b) are allocated on the primary grid (G). 


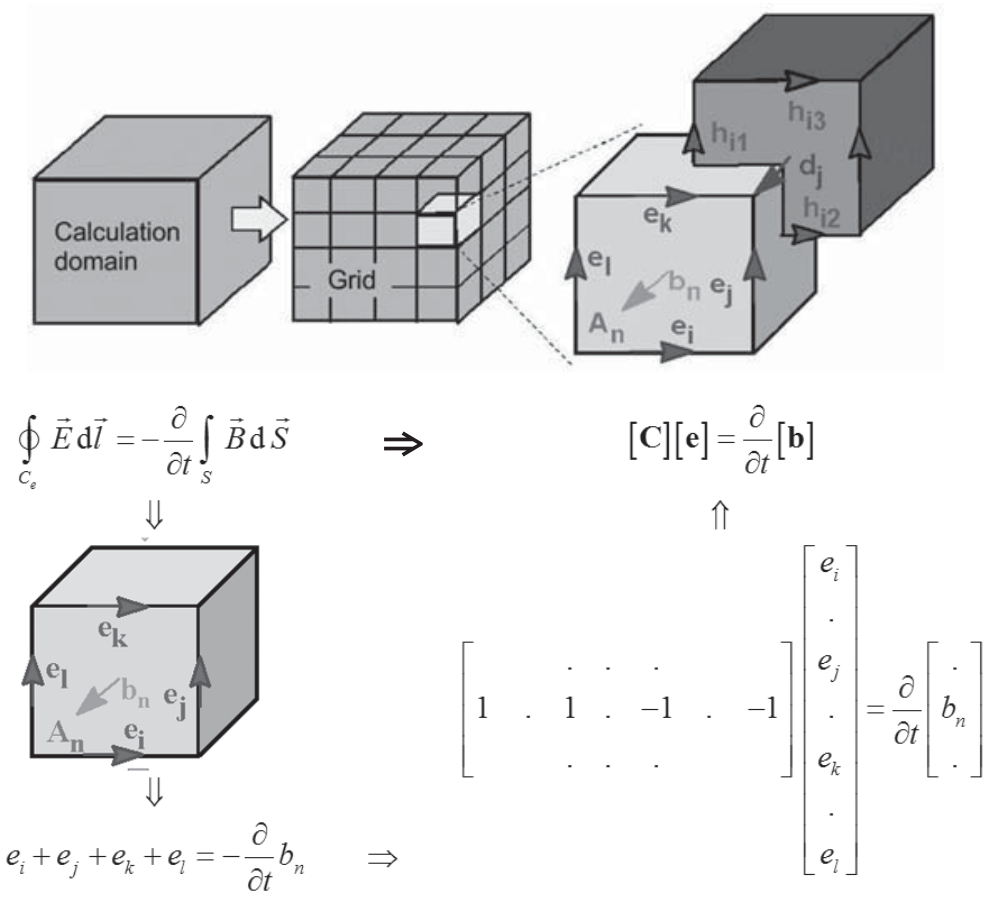

Maxwell's equations

$$
\begin{aligned}
& \oint_{C} \vec{H} \mathrm{~d} \vec{l}=\int_{S}\left(\vec{J}+\frac{\partial \vec{D}}{\partial t}\right) \mathrm{d} \vec{S} \\
& \oint_{C} \vec{E} \mathrm{~d} \vec{l}=-\int \frac{\partial \vec{B}}{\partial t} \mathrm{~d} \vec{S} \\
& \oint_{S} \vec{D} d \vec{S}=\int_{V} \rho \mathrm{d} V \\
& \oint_{S} \vec{B} d \vec{S}=0
\end{aligned}
$$

Maxwell's grid equations (MGEs)

$$
\begin{aligned}
& \tilde{\mathbf{C}} h=\frac{\mathrm{d}}{\mathrm{d} t} \mathbf{d}+\mathbf{j} \\
& \mathbf{C} \mathbf{e}=-\frac{\mathrm{d}}{\mathrm{d} t} \mathbf{b} \\
& \tilde{\mathbf{S}} \mathbf{d}=\mathbf{q} \\
& \mathbf{S} \mathbf{b}=0
\end{aligned}
$$

Figure 6 Review of Finite Integration Technique - geometric discretization method, Maxwell's equations and algebraic matrix equations.

In addition, the dielectric facet fluxes (d) as well as the magnetic grid voltages (h) are defined on the dual grid (shown by the tilde). Applying this scheme to Ampère's law on the dual grid requires identification of a corresponding dual discrete curl operator ( $\mathbf{C}$ tilde). Similarly, the discretization of the remaining divergence equations introduces discrete divergence operators ( $\mathbf{S}$ and $\mathbf{S}$ tilde), belonging to the primary and dual grids, respectively. As previously indicated (Figure 6), these discrete matrix operators consist of elements ' 0 ', ' 1 ' and '-1', representing merely topological information. Finally, the complete discretized set of Maxwell's Grid Equations (MGEs) is set up.

The FIT allows computationally fast implementations of numerical schemes that can be applied to simulate electromagnetic phenomena in three dimensions even for very complex structures (14-16).
For the simulation, the CST Studio Suite (EM simulation software based on the FIT method) (15) was used. The FIT method and accuracy of calculation by the CST Studio Suite software have been confirmed in numerous studies (17-19). The calculation of electromagnetic field penetration and absorbed energy is only a part of the suggested new procedure for investigating the biological effects of mobile phone radiation. For this reason, we will neither analyse nor compare the results of numerical penetrating field simulations with the research results from other authors. Numerical simulation results were often different because different models of phones were used (monoblock, flip, slider, swivel, etc.), the phones had different antennas (monopole, dipole, helix, and different types of PIFA), different radiation and different holding positions. Apart from that, the results of the absorbed field depended 
on the head model and its anatomical and morphological reality.

\section{Combining MRI and EM modelling for medical investigation}

In order to combine the numerical results of penetrated EM field components obtained by electromagnetic modelling and DICOM studies (research-based MRI image analysis of the human head), a 3D Slicer - a free open-source software package for visualization and image analysis (20) - was used. The 3D Slicer includes the ability to display arbitrarily oriented image slices, build surface models from image labels, as well as high performance volume rendering (Figure 7).

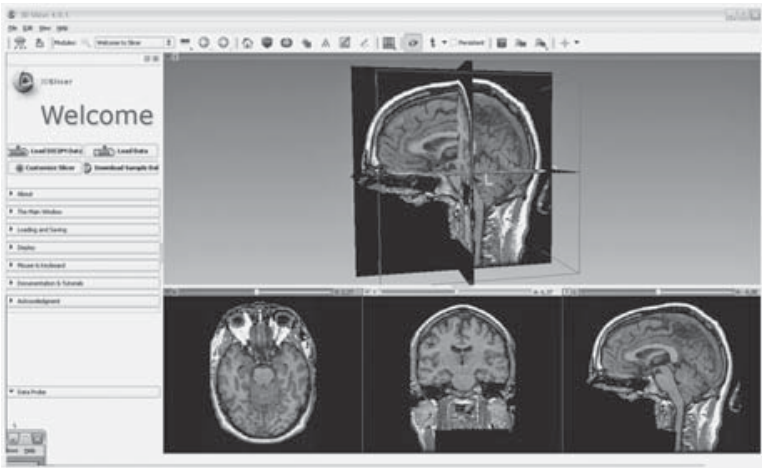

Figure 7 3D Slicer menu

The corresponding stereolithographic 3D Solid model of the human head (Modified EN 50361 SAM Phantom head, Figure 4) was imported into a 3D Slicer as shown in Figure 8.

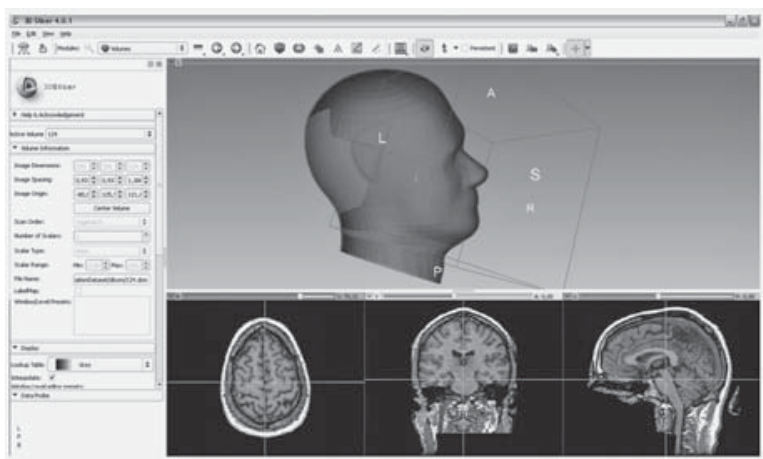

Figure 8 Importing a 3D solid model into the $3 D$ Slicer and combining it with MRI records obtained from DICOM.

\section{RESULTS}

The characteristics of the phone with PIFA, which was used for numerical calculation, were as follows: $\mathrm{f}=900 \mathrm{MHz}, \mathrm{P}=1 \mathrm{~W}$, and $\mathrm{Z}=50 \Omega$. The distance from the head (ear) to the edge of the mobile phone was $1 \mathrm{~cm}$. The values for SAR $[10 \mathrm{~g}]$ are shown in Figure 9. The guidelines and standard that specify SAR safety limits (i.e. IEEE C95.3) were used during calculation.

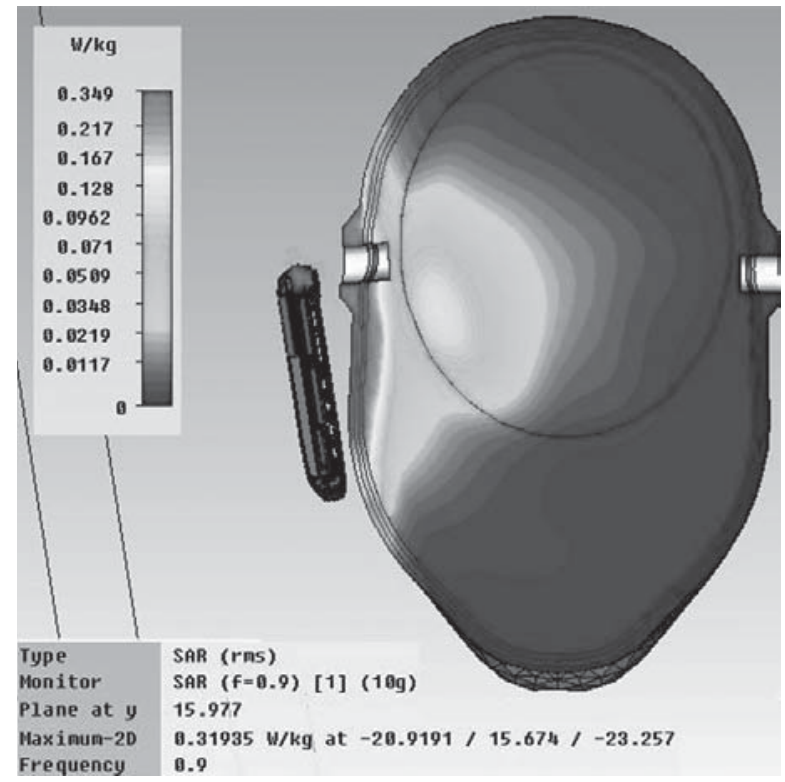

Figure 9 SAR normalized to $10 \mathrm{~g}$ mass

The values for SAR [1 g], electrical field, E; magnetic field, $\mathrm{H}$; induced current in tissue, $\mathrm{J}$; power density electrical, $\mathrm{w}_{\mathrm{e}}$; magnetic field, $\mathrm{w}_{\mathrm{m}}$; and power loss density can also be calculated. The results significantly change depending on the anatomical model of the head, type of mobile phone and its antenna, power consumption of mobile phone, numerical method of calculation, distance of the phone, as well as its position in relation to the head.

The results of combining MRI and EM modelling for medical investigation in accordance with the proposed method are shown in Figure 10 and Figure 11.

\section{DISCUSSION}

The results obtained with this new procedure anatomically locate the accurate positions in which an electromagnetic field maximum or energy absorption maximum have been observed. Medical experts can use this information to determine which parts of the brain, glands or areas of the body need to be examined for probable biological effects such 


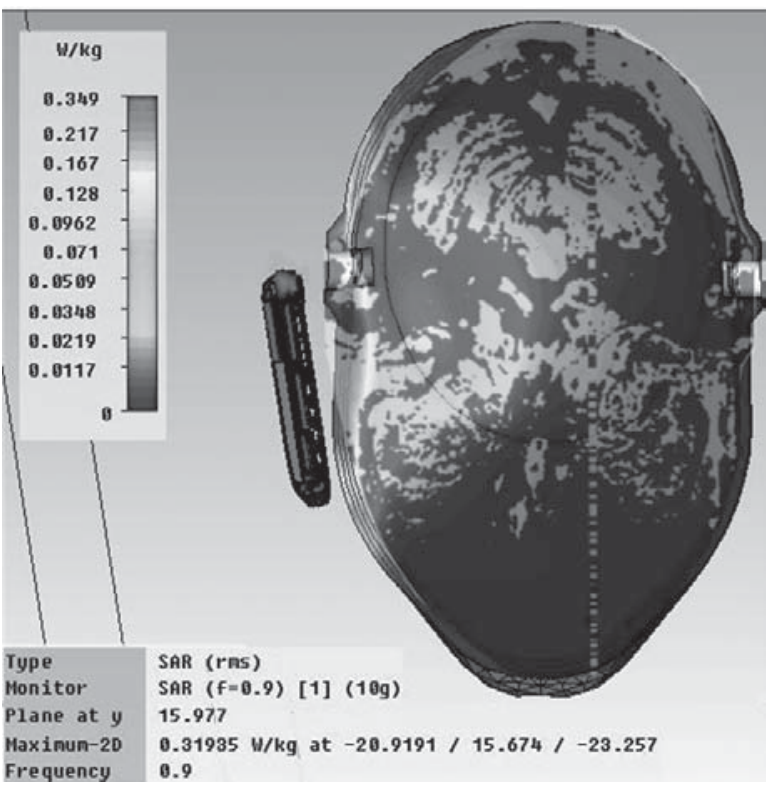

Figure 10 SAR normalized to $10 \mathrm{~g}$ mass with real structure of brain generated by MRI

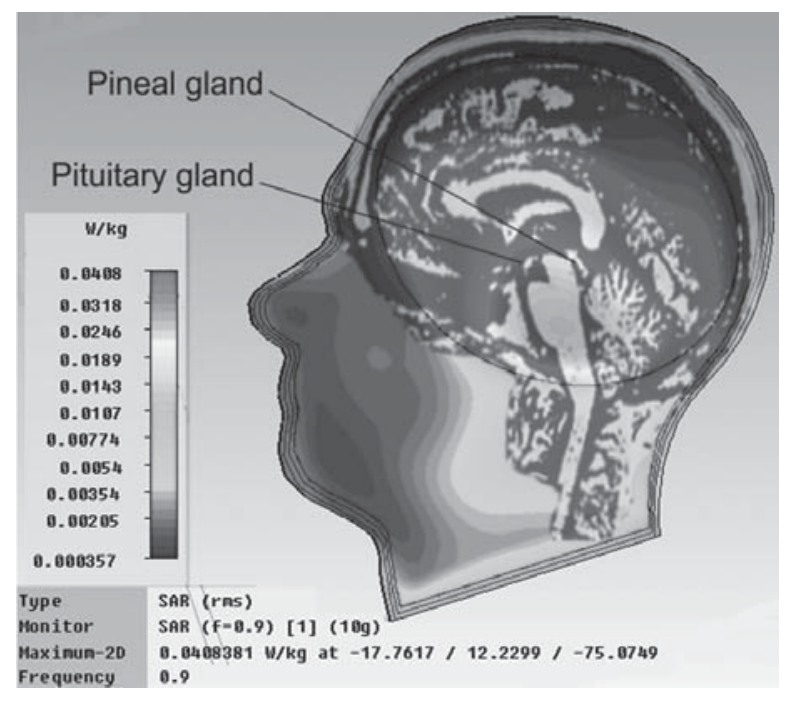

Figure 11 SAR normalized to $10 \mathrm{~g}$ mass with real structure of brain generated by MRI

as sleep disturbances, cognitive dysfunction, pituitary hormonal axis disorders or failure of the pineal gland.

Analysing the information in Figure 11, it is obvious that the highest radiation level of absorbed energy is located in the pineal gland, pituitary gland, and the structures in between. This is applicable only for the type of mobile phone and particular position shown in Figures 4 and 5.

The consistency of a model must be proven by biological and medical data. The highest absorbed energy of electromagnetic radiation in the area of the pineal and pituitary glands can account for the obtained results, which demonstrate that chronic exposure to electromagnetic radiation reduces the secretion of the neurohormone melatonin from the pineal gland $(15,22)$. It can also explain behavioural disorders registered in similar experiments using mobile phones (23). The unilateral effects of mobile phones proposed by the present study cannot explain sleep disturbances registered in animal and human models exposed to mobile phones (EMG disorders in humans using mobile phones). The use of a model for predicting the biological effects of mobile phone radiation which displayed maximal absorbed energy in the pineal and pituitary glands gives new insight into these disorders, as well as many other neurohumoral and immunological disorders.

Microwaves, specifically mobile phone high density waves, can cause detrimental effects on the central nervous, cardiovascular, haematopoietic, and reproductive systems (27-30). Especially interesting is the application of this model in oncology research involving the carcinogenic effects of mobile phones on brain structures. The procedure could be of great value in verifying SAR values in Case/Control studies of tumour occurrences caused by the use of mobile phones (32). The connection of the topographic location of maximum energy absorption and the primary place of a glioma (most cited brain tumour connected to mobile phone usage) could reveal the importance of this model.

Epidemiological research examining potential long-term risks from electromagnetic radiation exposure mostly focuses on the relationship between brain tumours and mobile phone usage. However, since a majority of cancers are not detectable until their interactions cause tumours, and considering that mobile phones have been used by the wider population for only 15 years, current epidemiological studies can only assess the cancers that become evident within shorter periods of time $(28,31)$.

\section{CONCLUSION}

Applying a model that determines the distribution of absorbed energy into brain structures would improve our understanding of the harmful effects of mobile phones, emphasising the different habits of mobile phone users - use of certain models, how one holds the phone, period of usage, etc. 
This procedure enables the correct detection of spots with maximum radiation, and therefore makes it possible to perform targeted biochemical studies. These targeted studies can significantly point out the health parameters of a patient's condition in terms of the exposure to electromagnetic fields. This procedure is applicable to a variety of technical resources in a wide frequency range.

The application of the above mentioned model is important in cases of occupational exposure to different sources. This way, the parameters of professional risk could be quantified more efficiently, whereas the measures involved in promoting occupational safety and health could be implemented more easily.

\section{Acknowledgements}

This work was supported by projects III43011 and III43012 of the Serbian Ministry of Education and Science.

\section{REFERENCES}

1. Aldair ER, Peterson RC. Biological effect of radiofrequency / microwave radiation. IEEE Trans Microw Theory Tech 2002;50:953-62.

2. Krstić D, Marković V, Nikolić N, Djindjić B, Radić S, Petković D, Marković M. Biološki efekti zračenja bežičnih komunikacionih sistema [Biological efects of exposure to mobile communication systems, in Serbian]. Acta Med Medianae 2004;43:55-63.

3. Weiland T. A discretization method for the solution of Maxwell's equations for six-component fields. Electron Commun (AEÜ) 1977;31:116-20.

4. Ragha LK, Bhatia BS. Numerical methods for bioelectromagnetic computation: a general perspective. Proceedings of SPIT-IEEE Colloquium and International Conference Mumbai, India 2007 [displayed 29 January 2013]. Available at http://conference.spit.ac.in/ieee colloquium/VLSI_and_Embedded_Systems/spit-85.pdf

5. Krstić D. Uticaj elektromagnetnih zračenja reda $\mathrm{GHz}$ na biološko tkivo [The influence of electromagnetic radiation in $\mathrm{GHz}$ bend on biological tissue, in Serbian]. [PhD thesis]. Niš: Faculty of Occupational Safety in Niš, University of Niš; 2010.

6. Gabriel C, Gabriel S, Corthout E. The dielectric properties of biological tissues: I. Literature survey. Phys Med Biol 1996;41:2231-49.

7. Gabriel S, Lau E, Gabriel C. The dielectric properties of biological tissues: III. Parametric model for the dielectric spectrum of tissues. Phys Med Biol 1996;41:2271-93.

8. Gabriel S, Lau E, Gabriel C. The dielectric properties of biological tissues: II. Measurement in the frequency range $10 \mathrm{~Hz}$ to $20 \mathrm{GHz}$. Phys Med Biol 1996;41:2251-69.
9. Gabriel C. Compilation of the Dielectric Properties of Body Tissues at RP and Microwave Frequencies. Brooks Air Force Technical Report AL/OE-TR-1996-0037, 1996.

10. Weiland T. Time domain electromagnetic field computation with finite difference methods. Int J Numer Model Electron Network Dev Field 1996;9:295-319.

11. Paulson KD. Computational bioelectromagnetics: modeling methods for macroscopic tissue interactions. In: Lin JC, editor. Advances in electromagnetic field in living systems. Vol. 2. New York (NY): Plenum Press; 1997. p. 63-128.

12. Wilson BW, Wright CW, Morris JE, Buschbom RL, Brown DP, Miller DL, Sommers-Flannigan R, Anderson LE. Evidence for an effect of ELF electromagnetic fields on human pineal gland function. J Pineal Res 1990;9:259-69.

13. STL (file format) [displayed 15 February 2012]. Available at http://www.en.wikipedia.org/wiki/STL_(file_format)

14. Krstić D, Zigar D, Petković D. Modeliranje apsorbcije zračenja mobilnog telefona u glavi čoveka [Modeling absorption electromagnetic radiation in human head, in Serbian]. In: Proceedings of the First International Symposium of the Biological Effects of Artificial Electromagnetic Fields; 29-30 May 2009; Novi Sad, Serbia. Novi Sad: Faculty Of Medicine; 2009. p 1-5.

15. CST STUDIO SUITE [displayed 15 February 2012]. Available at http://www.cst.com

16. Krstić D, Zigar D, Petković D, Sokolović D. Calculation of absorbed electromagnetic energy in human head radiated by mobile phones. Int J Emerg Sci 2011;1:52634.

17. Derat B, Bolomey J-Ch, Leray C. On the existence of a lower bound of SAR value for GSM mobile phone - a resonator based analysis. In: Proceedings of the $13^{\text {th }}$ International Symposium on Antennas (JINA'2004); 8-10 Nov 2004; Nice, France 2004. Nice: Université de Nice; 2004. p. 320-1.

18. Parazzini M, Tognola M, Franzoni C, Grandori F, Ravazzani P. Modeling of the internal fields distribution in human inner hearing system exposed to 900 and 1800 MHz. IEEE Trans Biomed Eng 2007;54:39-48.

19. Reeves JW, Birch MJ, Hand JW. Comparison of simulated and experimental results from helical antennas within a muscle-equivalent phantom. Phys Med Biol 2008;53:305770.

20. Slicer 3D [displayed 15 February 2012]. Available at http:// www.slicer.org

21. Hossmann KA, Hermann DM. Effects of electromagnetic radiation of mobile phones on the central nervous system. Bioelectromagnetics 2003;24:49-62.

22. Köylü H, Mollaoglu H, Ozguner F, Naziroglu M, Delibas N. Melatonin modulates $900 \mathrm{MHz}$ microwave-induced lipid peroxidation changes in rat brain. Toxicol Ind Health 2006;22:211-6.

23. Đinđić B, Radić S, Krstić D, Sokolović D, Pavlović T, Petković D, Radosavljević J. Exsposure to electromagnetic fields by using mobile telephone and its influence of the brain function. Facta Universitatis Ser Working Living Environ Protect 2004;2:311-6.

24. Oktem F, Ozguner F, Mollaoglu H, Koyu A, Uz E. Oxidative damage in the kidney induced by $900-\mathrm{MHz}$-emitted mobile phone: protection by melatonin. Arch Med Res 2005;36:3505. 
25. Burch JB, Reif JS, Noonan CW, Ichinose T, Bachand AM, Koleber TL, Yost MG. Melatonin metabolite excretion among cellular telephone users. Int J Radiat Biol 2002;78:102936.

26. Sokolović D, Djindjić B, Nikolić J, Bjelaković G, Pavlović D, Kocić G, Krstić D, Cvetković T, Pavlović V. Melatonin reduces oxidative stress induced by chronic exposure of microwave radiation from mobile phones in rat brain. $\mathrm{J}$ Radiat Res 2008;49:579-86.

27. Wiart J, Hadjem A, Gadi N, Bloch I, Wong MF, Pradier A, Hanna VF, Lautru D, Seze RD. Children head RF exposure analysis. In: Proceedings of the Joint Meeting of Bioelectromagnetics Society and the European Bioelectromagnetics Association; 19-24 June 2005; Dublin, Ireland. Dublin: Bioelectromagnetics Society; 2005. p. 1467. [CD-ROM]

28. World Health Organization (WHO). Electromagnetic fields and public health: mobile phones [displayed 23 February
2012]. Available at http://www.who.int/Mediacentre/ factsheets/fs193/en/

29. Lonn S, Ahlbom A, Hall P, Feychting M, and the Swedish Interphone Study Group. Long-term mobile phone use and brain tumor risk. Am J Epidemiol 2005;161:526-35.

30. Panagopoulos DJ, Chavdoula ED, Nezis IP, Margaritis LH. Cell death induced by GSM 900-MHz and DCS 1800-MHz mobile telephony radiation. Mutat Res 2007;626:69-78.

31. Marković V, Krstić D, Rančić OP, Sokolović D. Safety of mobile communication system radiation - recent findings. In: Proceedings of the $16^{\text {th }}$ Conference of the Series Man and Working Environment, International Conference Safety of Technical Systems in Living and Working Environment; 27-28 October 2011; Niš, Serbia. Niš: Faculty of Occupational Safety; 2011. p. 219-24.

32. Carlberg M, Hardell L. On the association between glioma, wireless phones, heredity and ionising radiation. Pathophysiology 2012;19:243-52. 


\section{Sažetak \\ MODEL ZA PREDVIĐANJE BIOLOŠKIH EFEKATA ZRAČENJA MOBILNIH TELEFONA: NUMERIČKI REZULTATI APSORBIRANE ENERGIJE POVEZANI S REALNOM STRUKTUROM DOBIVENOM METODOM MRI}

Numeričke bioelektromagnetne simulacijske metode prodrlih elektromagnetnih polja koriste se za izračunavanje komponenata polja u biološkim jedinkama.

Elektromagnetno polje nije jednako izvan i unutar biološkog subjekta. Izračunavanje energije apsorbirane iz poznatog izvora, kao što su mobilni telefoni u području glave, preduvjet je za ispitivanje biološkog utjecaja elektromagnetnog polja.

Pri ovim istraživanjima koriste se približni anatomski modeli i na osnovi njih se izračunavaju komponente polja i apsorbirana energija. Nužno je uspostaviti vezu između odgovarajućih približnih anatomskih modela s realnom strukturom, kako bi se mogli istraživati biološki efekti u dijelovima organa i tkiva.

Zbog toga se u ovom radu predlaže novi pristup istraživanju bioloških efekata. U osnovi metode je kombinacija dviju različitih tehnika: 1) numeričke elektromagnetne simulacije kojom se izračunavaju komponente polja u približnom anatomskom modelu i 2) MRI metoda (Magnetic resonance imaging) kojom se precizno lociraju mjesta s povišenom apsorpcijom. Kombiniranje se postiže preklapanjem slika dobivenih jednom i drugom metodom, čime se utvrđuje precizna lokacija mjesta s maksimalnim efektima apsorpcije. Na taj način mogu se pronaći mjesta na kojima bi trebao biti najizraženiji biološki učinak.

Novi pristup uspješno prevladava ograničenja koja su postojala pri radu s približnim anatomskim modelima.

KLJUČNE RIJEČI: elektromagnetno polje, izračunavanje stupca specifične apsorpcije (SAR), numeričko bioelektromagnetno modeliranje, precizno lociranje mjesta povećane apsorbirane energije

\section{CORRESPONDING AUTHOR:}

Dejan D. Krstić

University of Nis

Faculty of Occupational Safety in Niš

Čarnojevića 10a, 18000 Niš, Serbia

E-mail:dejank@znrfak.ni.ac.rs 